\title{
Comparison of the efficacies of two different Physical Therapy Treatment Programs in Patients With Lumbar Spinal Stenosis
}

\author{
Lumbar spinal stenozlu hastalarda iki farklı fizik tedavi programının \\ etkinliklerinin karşılaştırılması
}

\author{
Levent Ediz'1, Ozcan Hiz¹, Murat Toprak¹, İbrahim Tekeoğlu², Levent Yazmalar ${ }^{1}$ \\ 1 Yüzüncü Yıl Üniversitesi Tıp Fakültesi, Fiziksel Tıp ve Rehabilitasyon Anabilim Dalı, Van \\ 2 Sakarya Üniversitesi Tıp Fakültesi, Fiziksel Tıp ve Rehabilitasyon Anabilim Dalı, Sakarya
}

\begin{abstract}
Aim: To assess the effectiveness of therapeutic exercises and transcutaneus electrical nevre stimulation (TENS) alone and in combination with ultrasound (US) in patients with lumbar spinal stenosis.

Materials and Methods: In this randomized, prospective, controlled clinical trial which performed in Department of Physical Medicine and Rehabilitation, University Hospital, 48 patients presenting with symptoms of neurological claudication and magnetic resonance image-proven lumbar spinal stenosis were randomized to one of two 6-week (30 sessions, 5 session each week) physical therapy programs. One program included exercise + TENS group (group 1, $n=24$ ), while the other included exercise+TENS plus ultrasound (group 2, $n=24$ ). Stretching and strengthening exercises for lumbar, abdominal, leg muscles were given as therapeutic exercises. TENS was applied countinously with $80 \mathrm{MHz}$ frequency for 30 minutes. In addition to these treatment modalities ultrasound was applied with $1 \mathrm{mHz}, 1.5 \mathrm{~W} / \mathrm{cm} 2$ intensity, in continuous mode on the back muscle for 10 minutes to group 2 . Recovery was evaluated by Oswestry, a numerical pain rating scale (VAS), and a treadmill walking test. Testing occurred at baseline, 6 weeks, and 3 month.
\end{abstract}

Results: Statistically significant improvements were found in all of the post-treatment parameters (the leg pain score, Oswestry Disability Index score, treadmill walking distance) in both groups compared with the pre-treatment values in 6-weeks and 3-month follow-up evaluations $(p<0.05)$, Improvements in disability, satisfaction, VAS in exercise, TENS and US group (group 2) were significantly more than that of those in exercise, TENS group (group 1) at all follow-up points.

Conclusion: The results of our study suggest that patients with lumbar spinal stenosis can benefit from physical therapy. Therapeutic exercises and TENS are effective for pain and disability in patients with lumbar spinal stenosis and that addition of ultrasound to exercise therapy and TENS may further improve the parameters of follow-up in these patients.

Keywords: Lumbar spinal stenosis, Physical therapy, Rehabilitation, Ultrasound, TENS, Therapeutic exercises

Aplication: 14.01.2011 Accepted: 18.04.2011

\section{Özet}

Amaç: Lumbar spinal stenozlu hastalarda yalnızca terapötik egzersizler ve TENS (transcutaneus electrical nevre stimulation) ile birlikte US (ultrason) kombinasyonunun lumbar spinal stenozlu hastalarda etkinliğinin tespit edilmesi.

Materyal ve Metod: Üniversite hastanesi, Fiziksel tıp ve rhabilitasyon bölümünde yapılan bu randomize, prospektif, kontrollü klinik çalışmada, nörolojik kladikasyo semptomlu ve MRI ile ispatı lumbar spinal stenozlu 48 hasta iki 6 haftalık (30 seans, her hafta 5 seans) fizik tedavi programından birine randomize edildiler. Bir program egzersiz+TENS grubunu içerir iken (grup 1, $n=24$ ) diğeri egzersiz+TENS ek olarak ultrason grubunu içerdi (grup 2, n=24). Bel, karın, bacak kasları için germe ve güçlendirme egzersizleri terapötik egzersiz olarak verildi. TENS sürekli, $80 \mathrm{MHz}$ frekansta 30 dakika süre ile uygulandı. Grup 2 ye ek olarak ultrason 1 $\mathrm{mHz}, 1.5 \mathrm{~W} / \mathrm{cm} 2$ yoğunlukta, sürekli modda $10 \mathrm{dk}$. süre ile bel kaslarına uygulandı. lyileşme Oswestry, nümerik bir ağrı oranlama skalası (visual analog scale-VAS), ve Treadmill yürüme testi kullanılarak değerlendirildi. Değerlendirme testleri başlangıçta, 6 . haftada ve 3 . ayda yapıldı.

Bulgular: Tüm tedavi parametrelerinde (bacak ağrısı puanı, Oswestry Engellilik Endeksi puanı, koşu bandı yürüme mesafesi) 6. hafta ve 3 aylık takip değerlendirmelerinde tedavi öncesi değerlerle karşılaştırıldığında her iki grupta da istatistiksel olarak anlamlı fark bulundu $(p<0.05)$. Egzersiz, TENS ve US grubunda (grup 2) disabilite, memnuniyet, VAS taki gelişmeler tüm takip değerlendirmelerinde egzersiz, TENS grubundakinden (grup 1) daha anlamlı idi.

Sonuç: Çalışmamızın sonuçları lomber spinal stenozlu hastaların fizik tedaviden yarar sağlayabileceklerini düşündürmektedir. Terapötik egzersizler ve TENS ağrı ve disabilite için lomber spinal stenozlu hastlarda etkilidir ve ultrasonun, egzersiz ve TENS tedavisine eklenmesi bu hastalarda tedavi takip parametrelerini daha da geliştirebilir.

Anahtar kelimeler: Lumbar spinal stenoz, Fizik tedavi, Rehabilitasyon, Ultrason, TENS, Terapötik egzersizler

Başvuru Tarihi: 14.01.2011 Kabul Tarihi: 18.04.2011

Yazışma Adresi/Corresponding to: Levent Ediz, Yüzüncü Yıl Üniversitesi Tıp Fakültesi Fiziksel Tıp ve Rehabilitasyon Anabilim Dalı Van/Türkiye Tel: 05059951732 e-mail: leventediz@yyu.edu.tr 


\section{Introduction}

Lumbar spinal stenosis is characterized by diameter narrowing of spinal and radicular channel at segmentary or multiple levels. ${ }^{1}$ The narrowing beyond a critical level compresses the neural and neurovascular elements, resulting in neurologic symptoms in lower extremities. ${ }^{2}$

The most significant neurologic symptom in patients with LSS is intermittent claudication, which is defined as pain, numbness, feebleness, and/or cramps in one or both legs. These symptoms occurs when standing or walking beyond a threshold distance and subside when sitting, stooping, or bending forward. ${ }^{3}$

LSS is usually diagnosed with patient history and clinical findings, while magnetic rezonance imaging can provide additional information on the severity and level of stenosis. Surgical treatment is suggested in patients with severe symptoms of lumbar spinal stenosis. However, reported successful surgical outcomes vary. Additionally, there are many patients for whom surgery is not an option. ${ }^{4-7}$

It has been suggested that patients with LSS should receive a trial of conservative management especially physical therapy before surgery is considered. ${ }^{8}$ Developing optimal nonoperative management strategies in these patients is a high priority. The efficacy of the combined use of the physical therapies, has been evaluated by various studies. ${ }^{9-14}$

To our knowledge there are no randomized controlled studies evaluating the therapeutic benefits of exercise and TENS alone or combined use of a physical therapy modality such as ultrasound in patients with lumbar spinal stenosis. The objective of this study was to assess the effectiveness of therapeutic exercises and TENS alone and in combination with ultrasound.

\section{Materials and Methods}

Patients referred because of symptoms of neurogenic intermittent cladication (NIC) to Physical Medicine and Rehabilitation Department Outpatient Clinics and diagnosed with LSS based on clinical signs and symptoms and radiologic studies were eligible for the study. LSS was diagnosed if the patient has buttock or lower extremity pain, which may occur with or without back pain, associa- ted with symptoms of NIC and computerized tomography (CT) and/or lumbar vertebral magnetic resonance imaging (MRI) proven diminished space available for the neural and vascular elements in the lumbar spine. As mentioned above the diagnosis of LSS was confirmed with CT and/or MRI by the criterion of Measurements of anteroposterior diameter $<12 \mathrm{~mm}$. Presence of other pain syndromes in addition to LSS was accepted as an exclusion criterion. Patients meeting any of the following criteria were also excluded: severe coronary artery disease needed by-pass operation, pulmonary diseases such as chronic obstructive lung disease, asthma or tumors, history of spinal tumors or spinal infection; previous lumbar spinal surgery that included fusion or lumbar vertebral fractures other than spondylolysis or spondylolisthesis; and signs/symptoms suggestive of potential nonbenign or pathologic condition as the origin of symptoms. The hospital ethics committee approved the study and patients provided informed consent.

At baseline, the demographic data (age, sex, height, and weight) were obtained before randomization. Patients were randomized to the exercise and TENS group (group 1, $\mathrm{n}=24$ ), or the exercise+TENS and US group (group $2, n=24$ ) by an independent person who picked one of the sealed envelopes which contained numbers chosen by random number generator.

Patients in the two groups were instructed not to take neuropathic pain killers such as anticonvulsants, opioid or non-opioid analgesics, benzodiazepins and nonsteroidal anti-inflamatory and myorelaxant drugs but were allowed to take a maximum of $500 \mathrm{mg}$ paracetamol tablets three times a day in case of intense pain.

Conventional TENS (ITO Model 120 Z two channel TENS device [ITD Col. Ltd., Tokyo, Japan]) with a frequency of $80 \mathrm{~Hz}$ and pulse duration of $100 \mu$ second was applied for a total of 30 minutes to back muscles and both thighs.

Chattanooga Intelect (Hixson, USA) US machines were used during the study. The parameters were as follows: frequency $1 \mathrm{MHz}$, continuous mode, intensity 1,5 $\mathrm{W} / \mathrm{cm} 2$, and head size $5 \mathrm{~cm} 2$. Patients received 10 minutes of US therapy on the lumbar paravertebral region.

In both groups, the full exercise programme was completed in the exercise unit of the Physical Medicine 
and Rehabilitation Department under the supervision of a physiotherapist. In both groups flexibility exercise were performed as stretching of iliopsoas, hamstrings, quadriceps and lumbar paraspinal muscles, and strengthening exercises were performed by working with abdominal muscles and posterior pelvic tilt for 30 minutes. Either of these two physical therapy programs were applied for 5 days a week for six weeks for a total of 30 sessions to the patients.

Outcome Measures. Data regarding disability, pain, treadmill walking distance were collected at baseline, at the end of the treatment program (6 weeks), and at 3 month. The intensity of pain in the leg and lower back was measured using visual analogue scale set from 0 (no pain) to 10 (worst possible pain). Disability was assessed using the Oswestry Disability Index, where 0 indicates no disability and 100 indicates worst possible disability. ${ }^{15,16}$

Walking distance was measured by a treadmill at 0o inclination, with the body at a vertical position, at a speed of $2 \mathrm{~km} / \mathrm{h} .{ }^{17}$ The test was terminated when patients suffered of leg pain, and walking distance was determined. Walking distance expressed in meters.

All analyses were performed using SPSS statistical software, version 13.0 (SPSS Inc., Chicago, IL). Baseline status of the treatment groups were compared using two-tailed independent samples t tests, Chi-square tests of independence, and Mann-Whitney $U$ tests as indicated. Paired t-test was used to determine the changes between baseline and follow-up in each group. Mean improvements and differences between groups with 95\% confidence intervals were calculated for each of the outcome measures.

\section{Results}

Fourty-eight patients were enrolled over a 48-month period. No significant baseline differences were identified for demographics, baseline physical impairment, or outcomes between groups (Table 1).

The results of the study aresummarized in Table 2. Statistically significant improvements were found in all of the post-treatment parameters (the leg pain score, Oswestry Disability Index score, treadmill walking distance) in both groups compared with the pre-treatment values in 6-weeks and 3-month follow-up evaluations (Table 2).
Chart 1: Baseline Variables: Demographics, Outcome Measures, and Physical Impairments

\begin{tabular}{|l|c|c|c|}
\hline Variable & $\begin{array}{c}\text { Exercise and TENS } \\
\text { Group } \\
(\mathrm{n}=24)\end{array}$ & $\begin{array}{c}\text { Exercise, TENS and US } \\
\text { Group } \\
(\mathrm{n}=24)\end{array}$ & Significance (P) \\
\hline Age $(\mathrm{yr})$ & $63.4(6.3)$ & $65.6(7.2)$ & 0.66 \\
\hline Female $(\mathrm{n})(\%)$ & $15(62.5)$ & $13(54.1)$ & 0.08 \\
\hline BMI (kg/m2) & $26.57(3.79)$ & $27.34(4.02)$ & 0.57 \\
\hline Average straight leg raise $\left(^{\circ}\right)$ & $62.5(15.8)$ & $63.8(10.7)$ & 0.63 \\
\hline $\begin{array}{l}\text { Treadmill walking distance } \\
\text { (m) }\end{array}$ & $522.73(367.52)$ & $532.21(305.44)$ & 0.84 \\
\hline Oswestry Disability Index & $42.4(12.8)$ & $39.8(11.9)$ & 0.35 \\
\hline VAS-Lower Extremity Pain & $7.23(3.18)$ & $7.05(3.54)$ & 0.45 \\
\hline $\begin{array}{l}\text { Median duration of symptoms } \\
\text { (mo) }\end{array}$ & $67.4(0-804)$ & $63.7(6-744)$ & 0.71 \\
\hline
\end{tabular}

There were statistically significant differences between groups in terms of leg pain score, Oswestry Disability Index Score, treadmill walking distance, in favour of ultrasound added group in 6-weeks and 3-month follow-up evaluations (Table 2).

Chart 2: Mean Improvement From Baseline and Difference of Mean Improvement Between Groups for Study Outcomes.

\begin{tabular}{|c|c|c|c|}
\hline Variable & $\begin{array}{c}\text { Exercise, TENS group (n } \\
=24)(95 \% \mathrm{CI})\end{array}$ & $\begin{array}{c}\text { Exercise, TENS, and US } \\
\text { group }(\mathrm{n}=24)(95 \% \mathrm{CI})\end{array}$ & $\begin{array}{c}\text { Between-groups } \\
(95 \% \mathrm{CI})\end{array}$ \\
\hline \multicolumn{4}{|l|}{ Mean improvement in OSW } \\
\hline Baseline to 6-month follow-up & $8.78(2.75$ to 14.50$)$ & $12.48(6.5$ to 18.4$)$ & $\begin{array}{c}3.93(-3.07 \text { to } \\
10.03)\end{array}$ \\
\hline P-value & 0.015 & 0.001 & 0.024 \\
\hline Baseline to 3-month follow-up & 6.94 (1.68 to 11.42$)$ & 9.21 (3.6 to 12.2$)$ & $2.74(-2.12$ to 7.23$)$ \\
\hline P-value & 0.038 & 0.017 & 0.044 \\
\hline \multicolumn{4}{|c|}{ Mean improvement in treadmill walking distance $(\mathrm{m})$} \\
\hline Baseline to 6-week follow-up & 164.9 (8.8 to 371.2$)$ & $259.7(118.4-461.0)$ & $\begin{array}{l}146.2(-55.6 \text { to } \\
297.6)\end{array}$ \\
\hline P-value & 0.0043 & 0.0001 & 0.013 \\
\hline Baseline to 3-month follow-up & $112.3(-34.5$ to 256.7$)$ & $196.6(48.2$ to 263.7$)$ & $\begin{array}{c}67.6(-121.4 \text { to } \\
234.2))\end{array}$ \\
\hline P-value & 0.0089 & 0.0001 & 0.032 \\
\hline \multicolumn{4}{|c|}{ Mean improvement in VAS for lower extremity symptoms } \\
\hline Baseline to 6-week follow-up & $1.3(0.3-2.1)$ & $1.9(0.6$ to 2.9$)$ & $\begin{array}{l}0.51(-0.98 \text { to } \\
1.96) \\
\end{array}$ \\
\hline P-value & 0.027 & 0.012 & 0.039 \\
\hline Baseline to 3-month follow-up & $1.1(0.1$ to 1.8$)$ & $1.6(0.3$ to 2.3$)$ & $0.31(-0.43$ to 1.19$)$ \\
\hline P-value & 0.045 & 0.019 & 0.048 \\
\hline
\end{tabular}

\section{Discussion}

The generally accepted opinion for the treatment of LSS is the use of conservative therapies such as physical therapy and medications in mild and moderately symptomatic patients, and surgery in patients with severe symptoms. Evidence regarding the combination of physical therapy modalities is needed for informed decision making in the management of patients with LSS. 
The present study showed that the results of ultrasound plus exercise and TENS, and exercise and TENS alone treatments for lumbar spinal stenosis were effective based on the decrease in leg pain scores, the increase in treadmill walking distance and improvement of disability. The results of our study are encouraging and support that patients with LSS can achieve clinically important improvements with a physical therapy management program.

As in our results in terms of improvemnts in leg pain, disabilty scores and walking distance, there are several studies showing the effectiveness of physical therapy in the treatment of LSS. In these studies; as a conservative treatment, physical therapy modalities such as traction, US, short wave diathermy (SWD), TENS, ultrasound, different therapeutic exercises and body casts and braces were studied. ${ }^{18-27}$ Eventually, in a prospective study, it has been reported that a conservative treatment program consisting of physical therapy (infrared heating, ultrasonic diathermy and exercise) was effective on parameters evaluating pain and neurogenic claudication in patients with LSS. ${ }^{22}$ In a recent study, 89 patients with LSS have been treated by in-patient conservative treatment consisting of in-bed pelvic traction, application of body casts, and it has been reported that significant improvements were observed in symptoms, clinical signs and daily living activities after 2 weeks of conservative treatment.20 On the other hand, another study have failed to show the effectiveness of conservative treatment (conservative treatment consisted of 12 sessions of ultrasound waves, short waves, and flexion exercises) in LSS patients over 65 years old. ${ }^{29}$ Trials on exercise treatment particularly emphasize the importance of flexion exercises, and recommend the addition of aerobic exercises. ${ }^{28} \mathrm{~A}$ report of patients treated with a physical therapy program with a strengthening program, aerobic exercise, and flexion exercises suggests that perhaps the addition of a more developed strengthening program could be important. ${ }^{25}$ In a randomized controlled study, patients with LSS were treated by conservative treatment options; The first group received manual physical therapy, body weight-supported treadmill walking, and exercise, and the second group received flexion exercises, treadmill walking, and subtherapeutic ultrasound. ${ }^{9}$ Significant improvements were reported in both groups with more additional gains in the first group. In US used studies, contradictory results are reported on the effectiveness in LSS. ${ }^{29}$ But the diversity of physical therapy methods and outcome measures in these mentioned studies makes it difficult to compare their results with each other and our results.

In the current study we found that outcome measures (leg pain, disabilty scores and walking distance) in the ultrasound plus exercise group was better than that in the exercise and TENS only group. This suggests that supplementation of ultrasound to therapeutic exercises and TENS reduces the symptom severity in patients with LSS. However, there is still no consensus on the convenient parameters of the ultrasound (amplitude, pulse, duration, etc.).

Economically, addition of ultrasound therapy does not bring additional economic burden for patients with health insurance, because social security foundation in Turkey performs package pay for physical therapy practice for LSS treatment. As for patients without any health insurance, ultrasound therapy brings additional 2.5 Turkish Liras economic burden for each phsical therapy session which is a reasonable amount.

Limitations of the current study; a) The study is a study of 24 patients in both arm with very low statistical power, b) and shot term evaluations were performed (up to 3 months of follow-up), but the current data is enough to present the effectiveness of these two different physical therapy programs in the management of LSS.

In conclusion, our study showed that therapeutic stretching and strengthening exercises with TENS are beneficial with respect to improvement in level of pain, disability and walking distance in patients with lumbar spinal stenosis. Supplementation of ultrasound with therapeutic exercises and TENS is seen to be more beneficial to reduce the symptom severity and disability in patients with LSS. 


\section{References}

1. Miyamoto M, Genbum $\mathrm{Y}$, Ito $\mathrm{H}$. Diagnosis and treatment of lumbar spinal canal stenosis. J Nipon Med Sch 2002;69:583-7.

2. Fritz JM, Delitto A, Welch WC, et al. Lumbar spinal stenosis: a review of current concepts in evaluation, management, and outcome measurements. Arch Phys Med Rehabil 1998;79:700-8.

3. Porter RW. Spinal stenosis and neurogenic claudication. Spine 1996;21:2046-52.

4. Katz J, Lipson S, Chang L, et al. Seven to 10 year outcome of decompressive surgery for degenerative lumbar spinal stenosis. Spine 1996;21:92-8.

5. Tuite GF, Doran SE, Stern JD, et al. Outcome after laminectomy for lumbar spinal stenosis: II. Radiographic changes and clinical correlations. J Neurosurg 1994;81:707-15.

6. Johnsson KE, Uden A, Rosen I. The effect of decompression on the natural course of spinal stenosis: a comparison of surgically treated and untreated patients. Spine 1991;16:615-9.

7. Bodack M, Monteiro M. Therapeutic exercise in the treatment of patients with lumbar spinal stenosis. Clin Orthop Relat Res 2001:384:144-52.

8. Reindl R, Steffen $T$, Cohen $L$, et al. Elective lumbar spinal decompression in the elderly: is it a high-risk operation? Can J Surg 2003;46:43-6.

9. Whitman JM, Flynn TW, Childs JD et al. A comparison between two physical therapy treatment programs for patients with lumbar spinal stenosis. Spine 2006;31:2541-49.

10. Swezey RL. Outcome for lumbar spinal stenosis: a 5-year follow-up study. J Clin Rheumatol 1996;2:129-34.

11. Simotas AC, Dorey FJ, Hansraj KK, Cammisa F. Nonoperative treatment for lumbar spinal stenosis: clinical outcome results and 3-year survivorship analysis. Spine 2000;25:197-204.

12. Fritz JM, Erhard RE, Vignovic M. A nonsurgical treatment approach to patients with lumbar spinal stenosis. Phys Ther 1997;77:962-73.

13. Atlas SJ, Deyo RA, Keller RB et al. The Maine lumbar spine study, Part III: 1-year outcomes of surgical and nonsurgical management of lumbar spinal stenosis. Spine 1996;21:1787-94.

14. Atlas SJ, Keller RB, Wu AY, Deyo RA, Singer DE. Long-term outcomes of surgical and nonsurgical management of lumbar spinal stenosis: 8 to 10 year results from the maine lumbar spine study. Spine 2005;30:936-43.

15. Fairbank JC, Couper J, Davies JB, O'Brien JP. The Oswestry low back pain disability questionnaire. Physiotherapy 1980;66:271-73.

16. Pratt RK, Fairbank JCT, Virr A. The reliability of the shuttle walking test, the Swiss spinal stenosis questionnaire, the Oxford Spinal
Stenosis Score, and the Oswestry Disability Index in the assessment of patients with lumbar spinal stenosis. Spine 2002;27:84-91.

17. Fritz JM, Erhard RE, Delitto A, Welch WC, Nowakowsk PE.Preliminary results of the use of a two-stage treadmill test as a clinical diagnostic tool in the differential diagnosis of lumbar spinal stenosis. J Spinal Disord 1997;10:410-6.

18. Swezey RL. Outcome for lumbar spinal stenosis: a 5-year follow-up study. J Clin Rheumatol 1996;2:129-34

19. Atlas SJ, Deyo RA, Keller RB et al. The Maine lumbar spine study, Part III: 1-year outcomes of surgical and nonsurgical management of lumbar spinal stenosis. Spine 1996;21:1787-94.

20. Tadokoro K, Miyamoto H, Sumi M, Shimomura T. The prognosis of conservative treatments for lumbar spinal stenosis. Spine 2005;30:2458-63

21. Pua YH, Cai CC, Lim KC. Treadmill walking with body weight support is no more effective than cycling when added to an exercise program for lumbar spinal stenosis: a randomised controlled trial. Aust J Physiother 2007;53:83-89.

22. Onel D, Sari H, Donmez C. Lumbar spinal stenosis: clinical/radiologic therapeutic evaluation in 145 patients. Conservative treatment or surgical intervention? Spine 1993;18:291-98.

23. Pua YH, Cai CC, Lim KC. Treadmill walking with body weight support is no more effective than cycling when added to an exercise program for lumbar spinal stenosis: a randomised controlled trial. Aust J Physiother 2007;53:83-89

24. Athiviraham A, Yen D. Is spinal stenosis beter treated surgically or nonsurgically? Clin Orthop Relat Res 2007;458:90-93.

25. Hunter SJ, Fritz JM, Brennan GP. Variables associated with outcomes of physical therapy for patients with lumbar spinal stenosis. J Orthop Sports Phys Ther 2005;35:A14.

26. Creighton DS, Krauss J, Marcoux B. Management of lumbar spinal stenosis through the use of translatoric manipulation and lumbar flexion exercises: a case series. J Manual Manip Ther 2006; 14:E1-E10.

27. Pua YH, Cai CC, Lim KC. Treadmill walking with body weight support is no more effective than cycling when added to an exercise program for lumbar spinal stenosis: a randomised controlled trial. Aust J Physiother 2007;53:83-89.

28. Bodack MP, Monteiro M. Therapeutic exercise in the treatment of patients with lumbar spinal stenosis. Clin Orthop Relat Res 2001;384:144-52

29. Shabat S, Folman Y, Leitner Y, Fredman B, Gepstein R. Failure of conservative treatment for lumbar spinal stenosis in elderly patients. Arch Gerontol Geriatr 2007:44:235-41. 